\title{
Effect of Chloride Ions on the Point-of-Use Drinking Water Disinfection Performance of Porous Ceramic Media Embedded with Metallic Silver and Copper
}

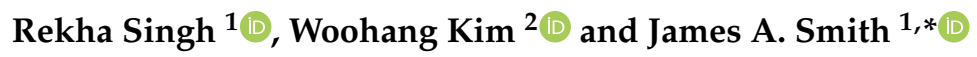 \\ 1 Department of Engineering Systems and Environment, University of Virginia, \\ Charlottesville, VA 22904, USA; fr5j@virginia.edu \\ 2 Department of Environmental Engineering and Biotechnology, Mokpo National Maritime University, \\ Mokpo 58628, Korea; whkim@mmu.ac.kr \\ * Correspondence: jas9e@virginia.edu
}

Received: 22 April 2020; Accepted: 29 May 2020; Published: 6 June 2020

\begin{abstract}
This study quantifies the effects of chloride ions on silver and copper release from porous ceramic cubes embedded with silver and copper and its effect on E. coli disinfection in drinking water. Log-reduction of $E$. coli by silver ions decreased after $4 \mathrm{~h}$ of contact time as the chloride ion concentration increased from 0 to $250 \mathrm{mg} / \mathrm{L}$ but, it was not changed by copper ions under the same conditions. For silver addition by silver-ceramic cubes, $\log$ reductions of $E$. coli decreased sharply from 7.2 to 1.6 after $12 \mathrm{~h}$ as the chloride concentration increased from 0 to $250 \mathrm{mg} / \mathrm{L}$. For the silver-ceramic cube experiments, chloride ion also reduced the total silver concentration in solution. After $24 \mathrm{~h}$, total silver concentrations in solution decreased from $61 \mu \mathrm{g} / \mathrm{L}$ to $20 \mu \mathrm{g} / \mathrm{L}$ for corresponding chloride ion concentrations. According to the MINTEQ equilibrium model analysis, the decrease in disinfection ability with silver embedded ceramic cubes could be the result of precipitation of silver ions as silver chloride. This suggests that $\mathrm{AgCl}$ was precipitating within the pore space of the ceramic. These results indicate that, although ionic silver is a highly effective disinfectant for E. coli, the presence of chloride ions can significantly reduce disinfection efficacy. For copper-ceramic cubes, $\log$ reductions of $E$. coli by copper embedded cubes increased from 1.2 to 1.5 when chloride ion concentration increased from 0 to $250 \mathrm{mg} / \mathrm{L}$. Total copper concentrations in solution increased from $4 \mu \mathrm{g} / \mathrm{L}$ to $14 \mu \mathrm{g} / \mathrm{L}$ for corresponding chloride ion concentrations. These results point towards the synergistic effect of chloride ions on copper oxidation as an increased concentration of chloride enhances copper release.
\end{abstract}

Keywords: silver; copper; disinfection; chloride ion; ceramic; E. coli

\section{Introduction}

Ceramic filters $(\mathrm{CFs})$ are known as one of the promising point-of-use water treatment technologies for turbidity or bacteria removal [1]. Ceramic filtration was developed to increase removal efficiency of microorganisms and has now become an increasingly studied method. In order to increase bacterial removal ability, some research has been studied on ceramic filter with metallic silver embedded $[2,3]$ or silver nanoparticles [4,5].

Metallic silver and silver nanoparticles are effective disinfectants owing to their unique properties such as high reactivity, high strength, and residual efficacy [6-9]. Silver has been known to have strong biocidal activity against bacteria, viruses, and protozoa $[10,11]$. Porous ceramic media embedded with silver has widely been used in recent decades for point-of-use water treatment, particularly in developing countries $[3,8,12,13]$. In aquatic environments, the release of silver from embedded ceramic 
is dependent on the rate of silver oxidation to produce silver ions, the primary species responsible for the disinfection [6]. In field tests, they are highly effective for disinfection of E. coli and coliform bacteria and had a lifespan of at least 6 months [9].

In general, copper is known to be safe for human consumption [14], but is a potentially toxic metal for bacteria, algae, and foodborne diseases [15-17]. Copper can be used as a disinfectant as copper is toxic to microorganisms and minimally toxic to human. Owing to its comparative disinfection efficacy and low cost, it could provide an affordable alternative for water treatment compared with silver [18].

Choi et al. [19] reported that chloride ions present in natural water reduce the disinfection ability of silver ions because chloride and silver react to form complexes. Singh et al. [20] concluded that chloride ions did not change the speciation of copper, but decreased disinfection was observed. Although the interaction between chloride and silver ions and the effect of chloride and silver ions toxicity have been studied $[10,19,20]$, the effect of chloride ion on silver releasing and disinfection has been explored in only a few studies [21]. This approach is valuable in that the end goal of these filters is to produce safe drinking water by reducing the microbial contamination. Levard et al. [21] showed the dissolution rate of silver nanoparticles was increased by increasing chloride ion concentration. Their results suggest that the kinetics of dissolution are strongly dependent on the $\mathrm{Cl} / \mathrm{Ag}$ ratio and toxicity to $\mathrm{E}$. coli is high at a high ratio of $\mathrm{Cl} / \mathrm{Ag}$. This result is not in agreement with other studies that show chloride ions lead to decreased disinfection ability $[19,20]$. So, there is a general lack of understanding about chloride ions impacts on both deposition and release of silver ions from silver embedded ceramic cubes [22]. Therefore, silver and copper release as a function of chloride concentration from metal embedded ceramic cubes is not well known and more research is needed to explain metal ions release from ceramic silver and copper embedded cubes and disinfection efficacy. The objective of this study is to quantify the effects of chloride ions on silver and copper release from silver- and copper-ceramic cubes and its resulting effect on $E$. coli disinfection. This study examined various concentrations of chloride ions $(0-250 \mathrm{mg} / \mathrm{L})$ and its effect on the disinfection efficacy of both silver and copper porous ceramic materials. E. coli disinfection batch experiments were conducted with silver as silver nitrate and copper as copper nitrate, respectively. Silver and copper release and disinfection experiments were conducted with cubes each of silver and copper embedded in aqueous phosphate buffer solutions. The initial and final concentration of E. coli at various time points was measured to understand the effect of chloride ions on disinfection.

\section{Materials and Methods}

\subsection{Silver and Copper Ceramic Cubes}

Silver and copper ceramic cubes were manufactured by combining $50 \mathrm{~g}$ of commercial redart clay, $5 \mathrm{~g}$ of 20-mesh sawdust, and $20 \mathrm{~mL}$ of an aqueous silver and copper nitrate solution $\left(0.5 \mathrm{~g} \mathrm{Ag}^{+}\right.$and $2.5 \mathrm{~g} \mathrm{Cu}^{2+}$ dissolved to make $20 \mathrm{~mL}$ of solution with deionized (DI) water, respectively). The wet mixture was rolled and pressed to $1 \mathrm{~cm}$ thickness using a pottery rolling slab. The pressed mixture was cut by square template to approximately $1 \mathrm{~cm}$ ceramic cubes. Additionally, wet ceramic cubes were dried for 3 days at room temperature and were fired using the following protocol: $150^{\circ} \mathrm{C} / \mathrm{h}$ until $600{ }^{\circ} \mathrm{C}$ and then at $300{ }^{\circ} \mathrm{C} / \mathrm{h}$ until $900{ }^{\circ} \mathrm{C}$ and held for $3 \mathrm{~h}$.

\subsection{Experimental Methods}

\subsubsection{Batch Experiment-E. coli Disinfection by Silver and Copper Ions}

For silver and copper nitrate batch experiments, silver ion and copper ion concentrations were $50 \mu \mathrm{g} / \mathrm{L}$ (silver as silver nitrate) and $500 \mu \mathrm{g} / \mathrm{L}$ (copper as copper nitrate), respectively. Chloride ion concentrations were varied from 0 to $250 \mathrm{mg} / \mathrm{L}$. E. coli disinfection ability was detected after $4 \mathrm{~h}$ and $24 \mathrm{~h}$. Initial E. coli concentrations at both time points were $10^{6} \mathrm{cfu}$. 


\subsubsection{Metals Release and E. coli Disinfection Experiments}

Silver ion and copper ion release tests were conducted with five cubes each of silver and copper embedded in $200 \mathrm{~mL}$ aqueous phosphate buffer solutions. E. coli disinfection in batch experiments was performed in $200 \mathrm{~mL}$ aqueous phosphate buffer solutions. Initial E. coli concentrations in all reactors were $10^{6} \sim 0^{8} \mathrm{cfu}$. Sodium thiosulfate was used in microbial testing to stop silver disinfection after specific disinfection time points of $4 \mathrm{~h}$ and $24 \mathrm{~h}$, selected based on literature and our experimental observations for microbial analysis.

\subsection{Analytical Methods}

\subsubsection{Characterization of Silver}

Transmission electron microscopy (TEM) was used to characterize the formation of silver nanopatches in ceramic. Samples were prepared by lightly scraping the ceramic surface into a solution of deionized water. TEM grids (Ted Pella Item No. 01822 Ultrathin Carbon A) were prepared with a drop of sample and allowed to dry under a laboratory fume hood. Grids were examined on an FEI (Field Electron and Ion Company, Hisboro, Oregon, OR, USA) Titan TEM (Transmission Electron Microscope) at $300 \mathrm{kV}$. Silver was chemically verified using energy dispersive spectroscopy (EDS) elemental analysis in scanning transmission electron microscopy (STEM) mode. Micrographs were created using a CCD digital camera (Gatan, Pleasanton, CA, USA). Size distribution and density of silver nanopatches were quantified using ImageJ processing software [20].

\subsubsection{Silver and Copper Analysis}

Total silver and copper concentrations were measured at various time points. Total silver concentrations were measured using an acetylene-air flame atomic absorption (AA) spectrometer (Perkin-Elmer HGA 900-AA200, Waltham, MA, USA), and a graphite furnace atomic absorption spectrometer (GFAA) (Perkin-Elmer AAnalyst 200, Waltham, MA, USA) for low silver levels, ensuring they were in the detectable range. AA and GFAA samples were prepared with nitric acid (1\%), to reduce chelation of ions, and were analyzed using cathode lamps specific to the element being measured.

A model 7900 inductively coupled plasma-mass spectrometer (ICP-MS) (Agilent Technologies, Santa Clara, CA, USA) was used to quantify copper in the samples. Sample analyses were performed in accordance with Environmental Protection Agency (EPA) Method 6020B from the SW-846 Hazardous Waste Test Methods Compendium. The samples were diluted to approximately 3\% nitric acid concentration using Type I (18.2 M $\Omega$ ) water for analysis. Helium gas was used as collision gas, while argon gas was used as a makeup gas for this analysis. Samples were introduced to the ICP-MS (Agilent 7900) using an SPS-4 auto-sampler. Before every analysis run, the instrument was calibrated using multi-metal standards (concentrations of $0.01,1,10,100$, and $1000 \mu \mathrm{g} / \mathrm{L}$ ). To match $3 \%$ nitric acid concentration of the samples, dilutions of the stock standard were made using trace metals grade nitric acid and DI water $(18.2 \mathrm{M} \Omega)$. All of the samples were analyzed in triplicate and mean sample values were recorded. Instrument detection limit for $\mathrm{Cu}$ was $0.0005 \mathrm{ppb}$.

\subsubsection{E. coli Measurement}

The United State Environmental Protection Agency (US-EPA) approved Colilert test was used to quantify viable E. coli in samples. This test uses defined substrate technology (DST) to detect E. coli. Colilert media was added to $100 \mathrm{~mL}$ sample and mixed thoroughly. The solution was poured into an IDEXX Quanti-tray and sealed using the Quanti-tray sealer and incubated for $24 \mathrm{~h}$ at $37^{\circ} \mathrm{C}$. E. coli use $\beta$-glucuronidase to metabolize 4-methylumbelliferyl-beta-D-glucuronide (MUG) and create fluorescence. As most non-coliforms do not have these enzymes, they are unable to grow and interfere. Using a fluorescent UV lamp, the trays were scanned to count fluorescent wells positive for $E$. coli concentration and correlated to E. coli concentration using a most probable number (MPN) table provided by the manufacturer (IDEXX Laboratories Inc, Westbrook, Maine, ME, USA). E. coli 
removal rate was expressed by $\log \mathrm{N} / \mathrm{N}_{0}$; where $\mathrm{N}_{0}$ and $\mathrm{N}$ represents the number of $E$. coli before and after treatment.

\section{Results and Discussion}

\subsection{Characterization Study}

Roughly spherical silver nanopatches on the ceramics were seen using TEM. A TEM image of Ag clusters produced is shown in Figure 1a. Silver nanopatches were confirmed to be metallic silver by energy-dispersive spectroscopy (EDS) and are spherical in morphology; Figure 1a,b. The observed nanocluster size distribution was around $10 \mathrm{~nm}$. The biggest size of Ag cluster was $18 \mathrm{~nm}$. Similar nanopatches were also reported by Singh et al. [13]. We tried extensively to image copper nano patches, but we have been unsuccessful in doing so. We were probably not able to image copper because of the interference with the coating material. However, we were able to do the copper confirmatory test using GFAA.

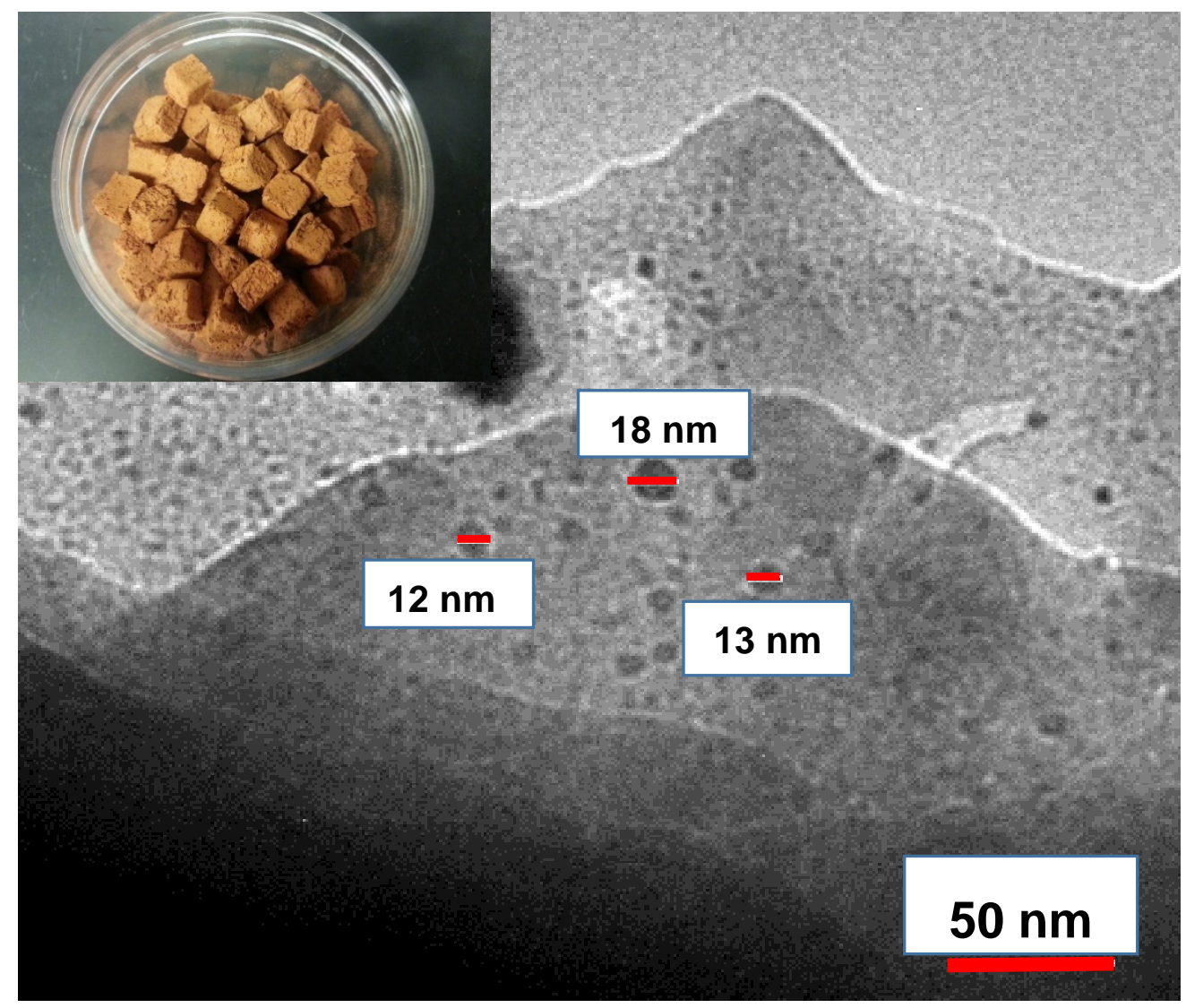

(a)

Figure 1. Cont. 


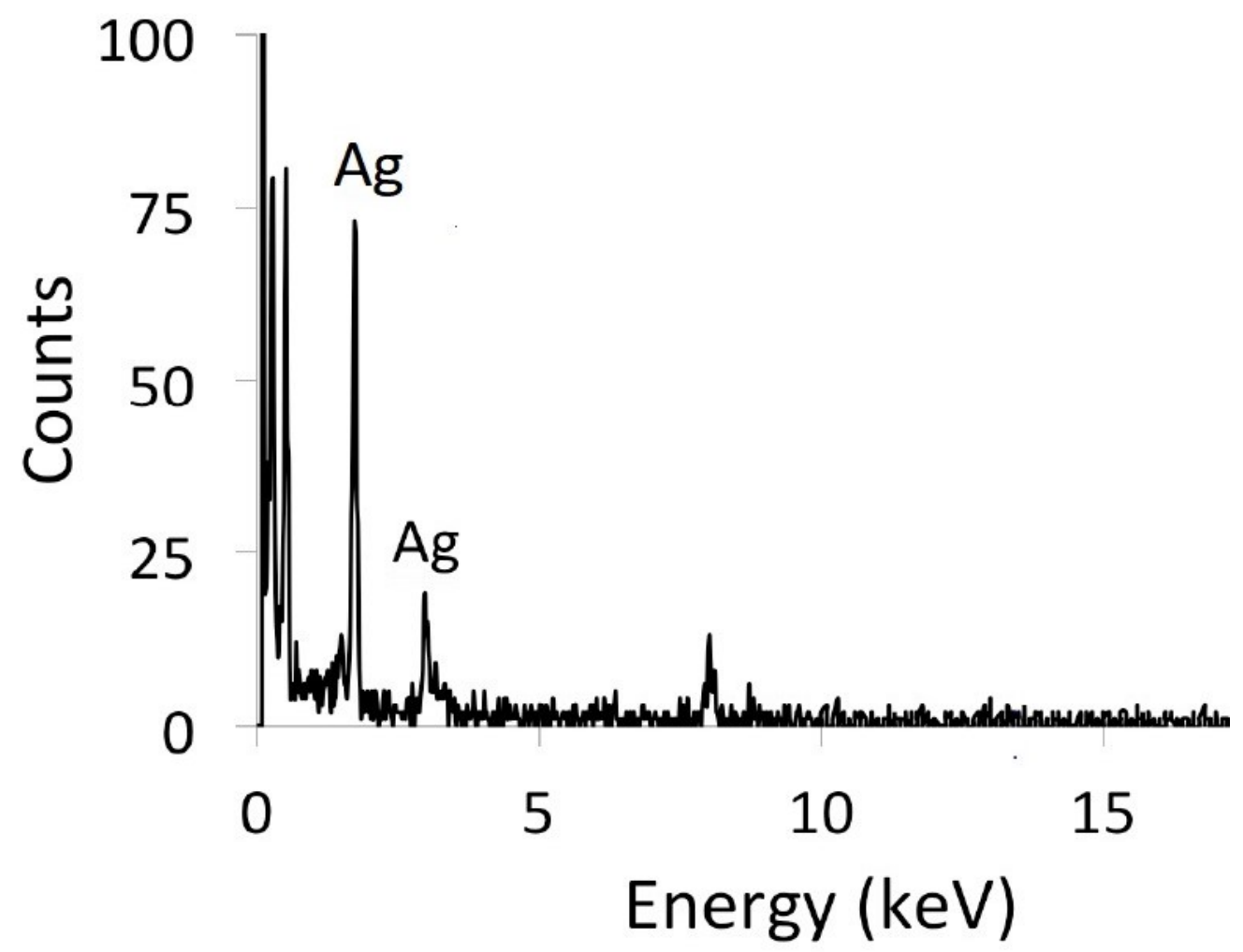

(b)

Figure 1. Characterization of Ag ceramic: (a) ceramic cubes; transmission electron microscopy (TEM) images of the silver patches in a ceramic cube; (b) X-ray energy dispersive (EDX) spectrum of Ag.

\subsection{Batch Experiments}

Figure 2 shows the disinfection of E. coli bacteria by silver and copper under chloride ion concentrations $(250 \mathrm{mg} / \mathrm{L})$. After $4 \mathrm{~h}$ of E. coli disinfection by silver ions in the presence of chloride, E. coli concentration reduction decreased from $5 \log$ to $1.8 \mathrm{log}$. Silver chloride ( $\mathrm{AgCl}$ ) was observed as a white precipitate in the batch reactors, which indicates that chloride ions decreased the rate of silver oxidation. Decreased disinfection of E. coli at a low concentration $(6 \mu \mathrm{g} / \mathrm{L})$ of silver ion and higher concentration $(30 \mathrm{mg} / \mathrm{L})$ of chloride ions was reported by Kahler et.al [7]. However, in this study, E. coli disinfection by silver ions was not changed at $24 \mathrm{~h}$ with the chloride ion treatment. It is important to note that, at the $24 \mathrm{~h}$ treatment, there is no increase in disinfection efficiency because E. coli was completely removed when there was no chloride ion in the solution.

Choi et al. [20] also reported that chloride ions present in natural water reduce the disinfection ability of silver ions because chloride ions react and form silver chloride complexes. Therefore, the reduced disinfection in the presence of chloride is likely owing to silver chloride and silver dichloride compounds that have weaker disinfection ability compared with silver ions. This was confirmed by the MINTEQ equilibrium model, where silver, silver chloride (AgCl), and silver dichloride $\left(\mathrm{AgCl}_{2}\right)$ ions concentration was $5 \%, 59 \%$, and 37\%, respectively. Although it was not observed with the naked eye in the solution because of the low concentration, it can be assumed that most of the precipitate was settled in the ceramic pore, as discussed by some other researchers [7].

However, E. coli disinfection by copper ions was not inhibited by chloride ions at 4 and $24 \mathrm{~h}$ time points. As the chloride ion does not react with copper, it had no effect on copper release or disinfection. MINTEQ equilibrium model shows only $1 \%$ of copper chloride ions $\left(\mathrm{CuCl}^{+}\right)$, while copper ions concentration was almost unchanged. 
Time (h)

4

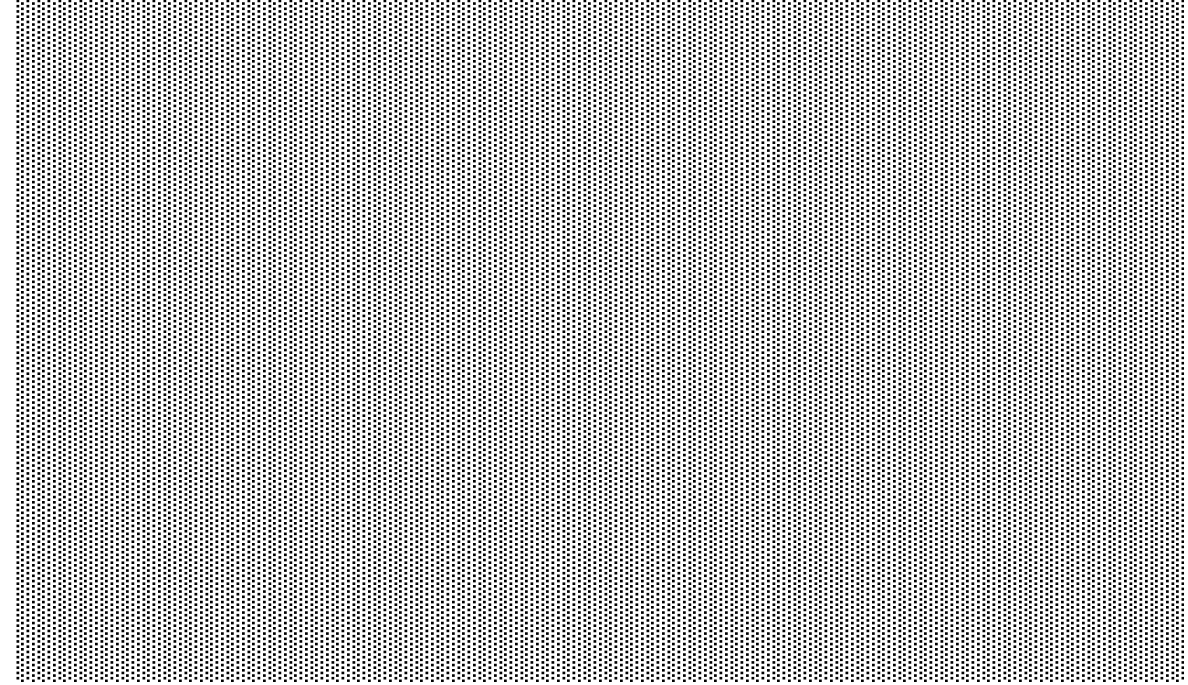

Figure 2. Comparison of $E$. coli reduction in the presence of chloride ion ( $250 \mathrm{mg} / \mathrm{L})$ with silver ions (50 ppb) and copper ions (500 ppb).

\subsection{MINTEQ Model}

The MINTEQ equilibrium model shows that an increased concentration of chloride ions led to a significant decrease in the concentration of silver ions (Figure 3). The release rate of silver ions from silver embedded ceramic cubes was decreased in the presence of chloride ions. Therefore, the decrease in disinfection ability could be because of precipitation of silver ions as silver chloride or silver dichloride.

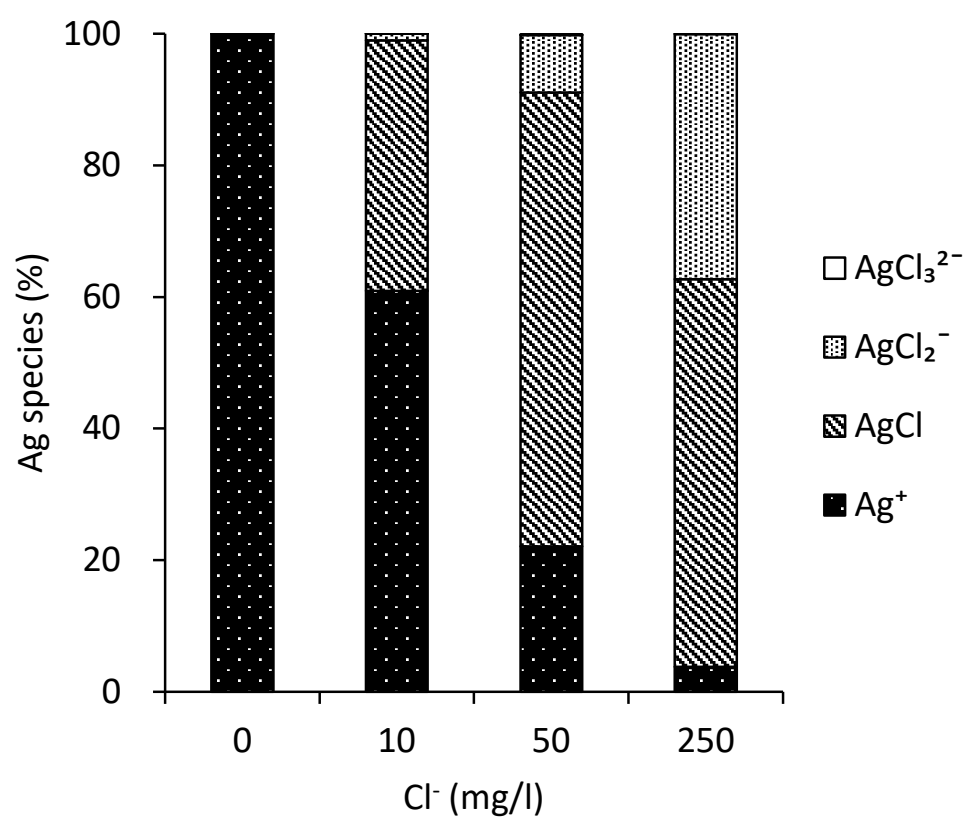

(a)

Figure 3. Cont. 


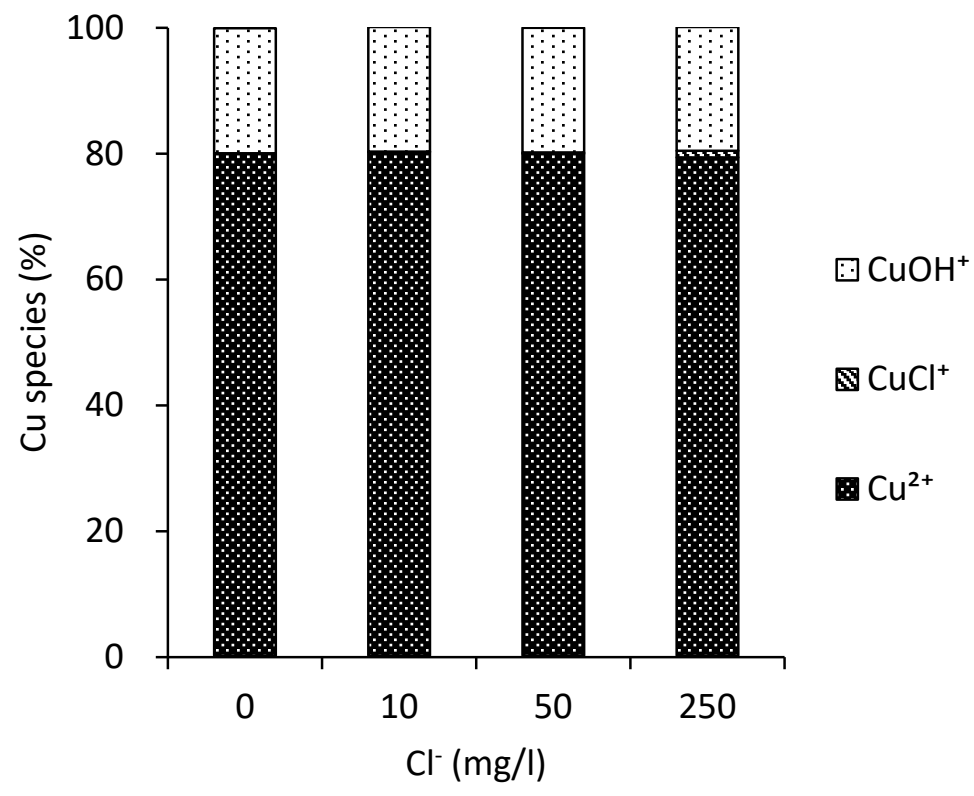

(b)

Figure 3. Effects of chloride ion on (a) silver species and silver ion release from silver embedded ceramic cubes; (b) copper species and copper ion release from copper embedded ceramic cubes.

Accordingly, silver disinfection of microorganisms was decreased by concentrations of chloride ion exceeding $25 \mathrm{mg} / \mathrm{L}$ [7]. Bacterial disinfection by silver chloride complexes was three times less than that by silver ion alone at $2.8 \mu \mathrm{M}$ concentration of silver [20]. This figure (Figure 3) shows that silver ions are the only species present in the absence of chloride ions. The silver ion component was changed to $61 \%, 22 \%$, and $4 \%$ with chloride ion concentrations of $10 \mathrm{mg} / \mathrm{L}, 50 \mathrm{mg} / \mathrm{L}$, and $250 \mathrm{mg} / \mathrm{L}$, respectively. The formation of silver chloride and silver dichloride resulted in decreased disinfection ability. Copper ion concentration was not significantly changed at the same condition $(79.1 \%$ to $80.0 \%$ ). This indicates that copper-embedded ceramic cubes are a better option for disinfection than silver-embedded ceramic cubes at high concentrations of chloride ions. According to the MINTEQ equilibrium model analysis, the speciation of copper was not significantly changed with the increasing concentration of chloride ions.

\subsection{Silver Trend Analytical Results}

For the silver-ceramic cube experiments, the silver concentration increased with time owing to the slow oxidation of silver in the presence of water. The oxidation causes a gradual release of silver ions from the porous ceramic substrate (Figure 4). This figure shows that silver release from the silver embedded cubes decreased with increased chloride concentrations.

The release of silver ions from the ceramic cube is decreased with the increasing concentration of chloride because silver ions precipitate with formation of silver chloride, thus diffusing into the ceramic cube through the pores [23].

It is known that metallic ions from the metal embedded ceramic are released and delivered through pores in the ceramic filter [17]. Silver release increases incrementally for ceramic tablets with increasing pore volume [6]. Choi et al. [20] reported that silver ions easily react with chloride ions in aqueous solution even at low concentrations. This means that release of silver ions can be precipitated with silver chloride as a compound in the pores of ceramic cubes. 


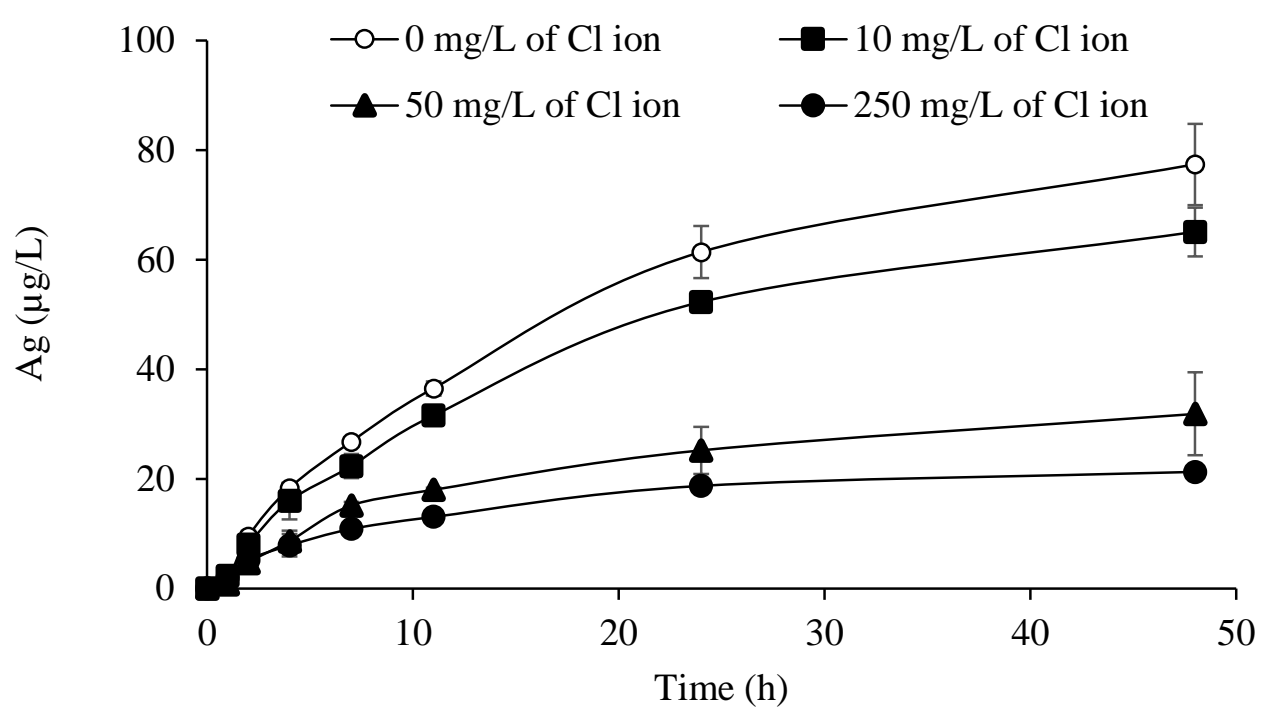

Figure 4. Trend of silver concentration $(\mu \mathrm{g} / \mathrm{L})$ in the presence of increasing chloride ion concentration with time in $200 \mathrm{~mL}$ DI water. Error bars represent standard error.

Figure 5 shows disinfection efficiency of silver-embedded cubes at different concentrations of chloride ions. At the $12 \mathrm{~h}$ treatment time, disinfection efficiency was high (7 log reduction) in the absence of chloride ions in the solution. Disinfection efficiency was decreased to 1.8, 1.6, and $-0.8 \log$ with addition of 10,50 , and $250 \mathrm{mg} / \mathrm{L}$ chloride ion, respectively. At the $24 \mathrm{~h}$ treatment, disinfection efficiency was increased to $6.8,5.8$, and $1.8 \log$ reduction with addition of 10,50 , and $250 \mathrm{mg} / \mathrm{L}$ of chloride ions, respectively.

Time (hr)

12

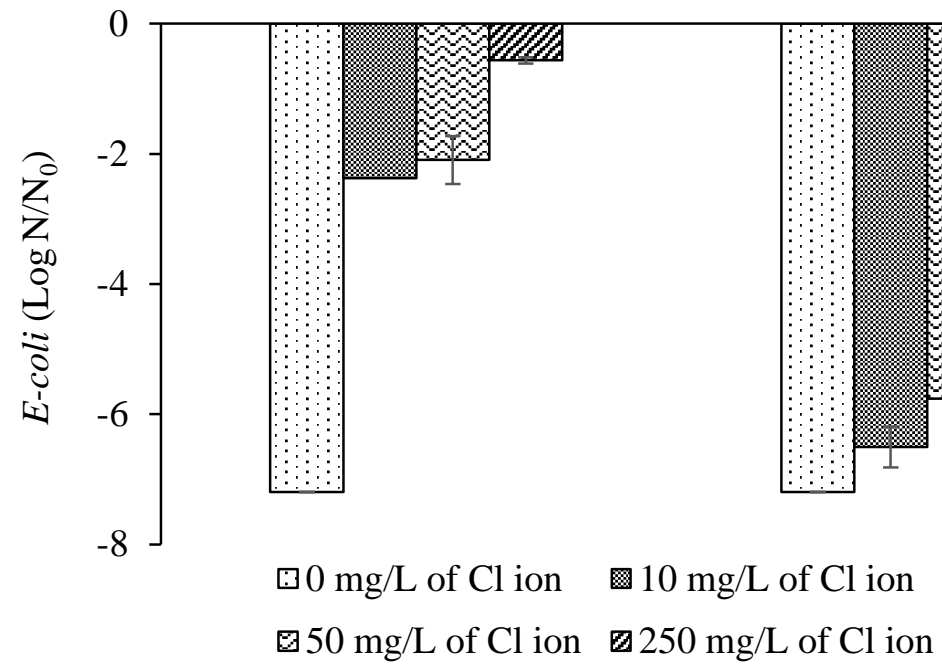

24

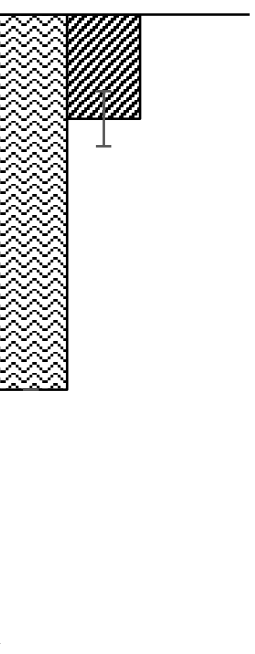

Figure 5. Disinfection of E. coli by silver embedded ceramic cubes after 12 and $24 \mathrm{~h}$ contact times in $200 \mathrm{~mL}$ DI water. Error bars represent standard error.

\subsection{Copper Disinfection Trend}

The concentration of released total copper was shown at different concentrations of chloride ion (Figure 6). Each sample had five copper embedded ceramic cubes (50 $\mathrm{mg} \mathrm{Cu}$ per each cube) in $200 \mathrm{~mL}$ of phosphate buffer solution. This concentration of copper ions increased sharply for $6 \mathrm{~h}$, but reached a steady state after an additional $6 \mathrm{~h}$. The experiment was performed with ceramic cubes containing five times more copper than silver because of the slow oxidation of copper ions from the 
ceramics. Silver is approximately 10 times more effective in disinfection based on our lab experiments. Moreover, the World Health Organization (WHO) permissible limit for copper is 10 times higher than silver $(0.1 \mathrm{mg} / \mathrm{L}$ for silver and $1 \mathrm{mg} / \mathrm{L}$ for copper). We planned these experiments after taking into account all these factors. However, the actual concentration of copper released was found to be less than the concentration of silver. Jackson et al. [9] also reported that release of copper was lower than that of silver. Moreover, these data show that the concentration of copper was increased by increasing chloride ions. It seems that there is a synergistic effect of chloride ion on copper oxidation. Copper oxidation can be affected by chloride ions at a low concentration of copper [24]. In addition, the oxidation mechanism of copper is strongly dependent on the presence of chloride ions $[25,26]$.

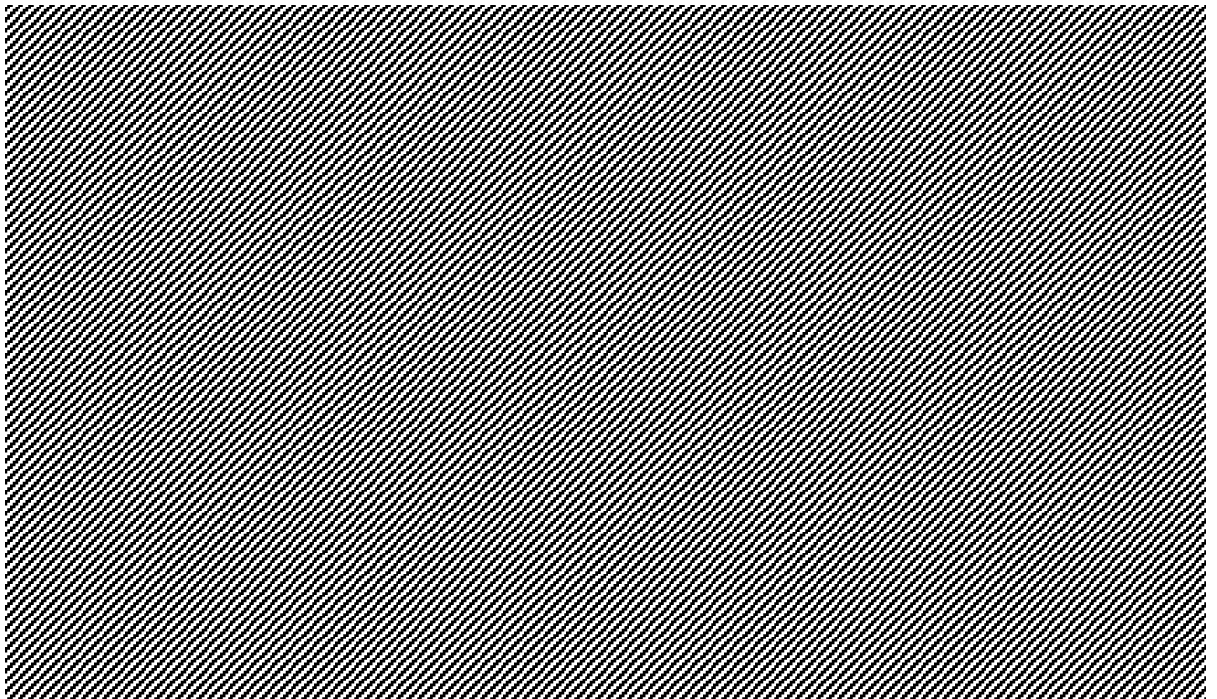

Figure 6. Total copper concentration in $200 \mathrm{~mL}$ DI water at various time points as a function of chloride ion concentration. Error bars represent standard error.

At the $12 \mathrm{~h}$ treatment, disinfection efficiency was increased with increasing concentration of chloride ions; $\log$ reduction of $E$. coli was $0.6,0.8,0.9$, and 1.1 at a chloride concentration of $0,10,50$, and $250 \mathrm{mg} / \mathrm{L}$, respectively (Figure 7). Log reduction of E. coli increased to 0.9, 1.4, 1.9, and 2.6 at $24 \mathrm{~h}$ treatment. Disinfection efficiency of copper embedded cubes was increased by increasing concentration of chloride ions owing to the positive effect of chloride ions on the copper oxidation rate. Disinfection efficiency of copper-embedded cubes was lower than that of silver-embedded cubes. This is because of the slower copper oxidation rate and lower disinfection ability compared with silver ions.

Although copper disinfection efficiency is lower than that of silver, it is important to consider its affordable cost and 99\% disinfection efficacy. Taking this into account, copper cubes make for an appealing disinfection option, especially in areas with high chloride ions in water.

Some field studies reported that even a very low concentration of silver and copper results in good disinfection [7-9]. This ceramic technology can be used for drinking water disinfection and has a real-world application as point of use (POU) technology in developing counties. This technology provides a passive silver delivery method where silver is released in a controlled rate that eventually reaches a steady-state, assuring silver levels remain below the WHO drinking water standard of $0.1 \mathrm{mg} / \mathrm{L}$. Moreover, this technology has a long shelf life, and no electricity is needed. Kahler et al. [7] reported the economic viability of this product (using silver). They also conducted a field study in South Africa and examined a cost model based on the "willingness to pay" study. Therefore, there is practical evidence that the silver ceramic technology described here can be commercially viable. Moreover, silver is currently used in a variety of commercial point-of-use water treatment products, including pot-shaped ceramic water filters promoted by nonprofit organizations, such as Potters for Peace, Pure Madi, and Wine to Water [13]. The current study was a laboratory experimental effort to understand the hypothesis that chloride ions 
interfere with the disinfection process. Although, filters with an even lower concentration of silver ions have shown good disinfection efficacy under real-world conditions [3].

Time (h)

12

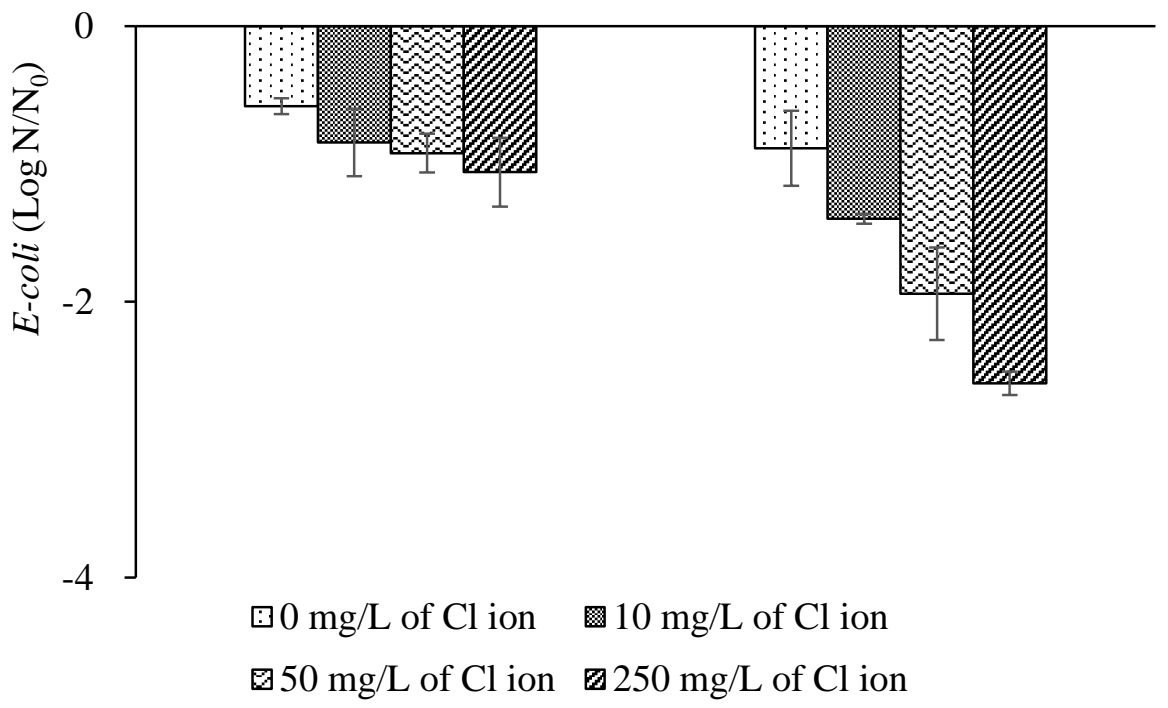

Figure 7. Disinfection of E. coli by copper embedded ceramic cubes after 12 and $24 \mathrm{~h}$ contact times. Error bars represent standard error.

If we compare this ceramic technology with chlorination, chlorine-based disinfection technologies are also very effective. However, these technologies have several limitations, including their ineffectiveness against protozoan pathogens, poor social acceptance owing to a change in the taste of the water, the possible formation of various disinfection byproducts (DBPs), and the emergence of microorganisms that are resistant to chlorine disinfection [27-29]. Although, with the increasing commercialization of nanosilver, there are growing concerns about the development of nanosilver-resistant microorganisms. These concerns are judicious, considering the problems worldwide caused by antibiotic-resistant microorganisms owing to the widespread use of antibiotics [30]. Before the introduction of antibiotics as medicines, antibiotic resistance genes were not identified on plasmids. However, genes that protect against different antibiotics and certain heavy metals (copper and silver) are commonly found on the same plasmids. The potential for selection of silver resistance in Gram-negative bacteria varies considerably between species [31]. In this study [31], no decrease in silver disinfection was observed in Pseudomonas aeruginosa, Acinetobacter baumannii, C. freundii, and $S$. sonnei during 42 days of continuous treatment with $\mathrm{AgNO}_{3}$. Nevertheless, the authors suggested that there would be a benefit in surveillance programs to monitor the emergence and spread of silver-resistant isolates for the use of antimicrobial silver for non-medical purposes. This investigation focused on the effects of chloride ions on disinfection by silver and copper oxidized and released from a porous ceramic substrate. It should be noted that other water quality parameters such as turbidity and dissolved organic matter (DOM) content might affect metal oxidation from nanopatches and metal ion disinfection performance. DOM or turbidity particles may block pores on the ceramic substrate or deposit directly on nanopatches and reduced metal oxidation and/or diffusion of the oxidized metal cation out of the porous ceramic substrate. DOM may also directly alter metal ion toxicity [32]. One prior study reports that binding of silver ions to humic substances did not have an effect on bacterial growth. Future research is needed to better understand the role of these water quality parameters on metal-ion disinfection [33]. 


\section{Conclusions}

In this study, we compared silver and copper disinfection efficacies in the presence of chloride ions using silver and copper salts and silver and copper cubes. In the batch experiment where silver was added as silver nitrate, log reductions of $E$. coli ranged from 5.1 to 1.7 after $4 \mathrm{~h}$ of contact time as the chloride ion concentration increased from 0 to $250 \mathrm{mg} / \mathrm{L}$. However, the change in log reductions of $E$. coli by copper nitrate under the same conditions was almost negligible. For silver addition by silver-ceramic cubes, E. coli disinfection decreased sharply with increasing chloride concentrations ( 0 to $250 \mathrm{mg} / \mathrm{L}$ ) after $12 \mathrm{~h}$. This result strengthens the fact that chloride ions also reduced the total silver concentration in the solution. This suggests that $\mathrm{AgCl}$ was forming and precipitating within the pore space of the ceramic. These results indicate that ionic silver is a highly effective disinfectant for $E$. coli. However, high levels of the chloride ion can significantly reduce disinfection efficacy. For copper addition by copper-ceramic cubes, disinfection of $E$. coli was sharply increased after $12 \mathrm{~h}$ as the chloride concentration increased from 0 to $250 \mathrm{mg} / \mathrm{L}$. This result shows that chloride ions aid the release of copper ions into solution, simultaneously increasing disinfection efficiency.

Author Contributions: W.K., R.S., and J.A.S. conceived the presented idea and verified the analytical methods. W.K. and R.S. carried out the experiment and wrote the manuscript with support from J.A.S. All authors have read and agreed to the published version of the manuscript.

Funding: This research received no external funding.

Acknowledgments: Authors are thankful to Tony Singh, who assisted with the analysis.

Conflicts of Interest: The authors declare no conflict of interest.

\section{References}

1. Lamichhane, S.; Kansakar, B.R. Comparison of the Performance of Ceramic Filters in Drinking Water Treatment. Int. J. Eng. Innov. Technol. 2013, 3, 481-484.

2. Mellor, J.E.; Kallman, E.; Oyanedel-Craver, V.; Smith, J.A. Comparison of Three Household Water Treatment Technologies in San Mateo Ixtatán, Guatemala. J. Environ. Eng. ASCE 2015, 14, 04014085. [CrossRef]

3. Jackson, K.N.; Smith, J.A. A New Method for the Deposition of Metallic Silver on Porous Ceramic Water Filters. J. Nanotechnol. 2018, 2018. [CrossRef]

4. Kallman, E.N.; Oyanedel-Craver, V.A.; Smith, J.A. Ceramic Filters Impregnated with Silver Nanoparticles for Point-of-Use Water Treatment in Rural Guatemala. J. Environ. Eng. ASCE 2011, 137, 407-415. [CrossRef]

5. Bielefeldt, A.R.; Stewart, M.W.; Mansfield, E.; Summers, R.S.; Ryan, J.N. Effects of chlorine and other water quality parameters on the release of silver nanoparticles from a ceramic surface. Water Res. 2013, 47, 4032-4039. [CrossRef]

6. Ehdaie, B.; Krause, C.; Smith, J.A. Porous Ceramic Tablet Embedded with Silver Nanopatches for Low-Cost Point-of-Use Water Purification. Environ. Sci. Technol. 2014, 48, 13901-13908. [CrossRef]

7. Kahler, D.M.; Koermer, N.T.; Reichl, A.R.; Samie, A.; Smith, J.A. Performance and Acceptance of Novel Silver-Impregnated Ceramic Cubes for Drinking Water Treatment in Two Field Sites: Limpopo Province, South Africa and Dodoma Region, Tanzania. Water 2016, 8, 95. [CrossRef]

8. Ehdaie, B.; Rento, C.T.; Son, V.; Turner, S.S.; Samie, A.; Dillingham, R.A.; Smith, J.A. Evaluation of a Silver-Embedded Ceramic Tablet as a Primary and Secondary Point-of-Use Water Purification Technology in Limpopo Province, S. Africa. PLoS ONE 2017, 12, e0169502. [CrossRef]

9. Jackson, K.N.; Smith, J.A.; Edokpayi, J.N. New Method for the Deposition of Metallic Silver and Metallic Copper on Full-Size Porous Ceramic Water Filters. Environ. Eng. Sci. 2019, 36, 2-11. [CrossRef]

10. Swathy, J.R.; Sankar, M.U.; Chaudhary, A.; Anshup, S.A.; Pradeep, T. Antimicrobial silver: An unprecedented anion effect. Sci. Rep. Nat. 2014, 4, 7161. [CrossRef]

11. Pathak, S.P.; Gopal, K. Evaluation of bactericidal efficacy of silver ions on Escherichia coli for drinking water disinfection. Environ. Sci. Pollut. Res. 2012, 19, 2285-2290. [CrossRef] [PubMed]

12. Halem, D.; Laan, H.; Heijman, S.G.J.; Dijk, J.C.; Amy, G.L. Assessing the sustainability of the silver-impregnated ceramic pot filter for low-cost household drinking water treatment. Phys. Chem. Earth 2009, 34, 36-42. [CrossRef] 
13. Singh, R.; Rento, C.; Son, V.; Turner, S.; Smith, J.A. Optimization of Silver Ion Release from Silver-Ceramic Porous Media for Household Level Water Purification. Water 2019, 11, 816. [CrossRef]

14. Olivares, M.; Uauy, R. Copper as an essential nutrient. Am. J. Clin. Nutr. 1996, 63, 791-796. [CrossRef]

15. Chen, N.H.; Chung, C.J.; Chiang, C.C.; Chen, K.C.; He, J.L. Antimicrobial and decorative ion-plated copper-containing ceramic coatings. Surf. Coat. Technol. 2013, 236, 29-35. [CrossRef]

16. Palza, H.; Quijada, R.; Delgado, K. Antimicrobial polymer composites with copper micro- and nanoparticles: Effect of particle size and polymer matrix. J. Bioact. Compat. Polym. 2015, 30, 366-380. [CrossRef]

17. Drelich, A.J.; Miller, J.; Donofrio, R.W.; Drelich, J.W. Novel Durable Antimicrobial Ceramic with Embedded Copper Sub-Microparticles for a Steady-State Release of Copper Ions. Materials 2017, 10, 775. [CrossRef]

18. Dankovich, T.A.; Smith, J.A. Incorporation of copper nanoparticles into paper for point-of-use water purification. Water Res. 2014, 63, 245-251. [CrossRef]

19. Choi, O.; Deng, K.K.; Kim, N.J.; Ross, L., Jr.; Surampalli, R.Y.; Hu, Z. The inhibitory effects of silver nanoparticles, silver ions, and silver chloride colloids on microbial growth. Water Res. 2008, 42, 3066-3074. [CrossRef]

20. Singh, R.; Edokpayi, J.N.; Odiyo, J.O.; Smith, J.A. E. coli Inactivation by Metals and Effects of Changes in Water Chemistry. J. Environ. Eng. 2019, 145, 040181. [CrossRef]

21. Levard, C.; Mitra, S.; Yang, T.; Jew, A.D.; Badireddy, A.R.; Lowry, G.V.; Brown, G.E., Jr. Effect of Chloride on the Dissolution Rate of Silver Nanoparticles and Toxicity to E. coli. Environ. Sci. Technol. 2013, 47, 5738-5745. [CrossRef] [PubMed]

22. Mittelman, A.M.; Lantagne, D.S.; Rayner, J.; Pennell, K.D. Silver Dissolution and Release from Ceramic Water Filters. Environ. Sci. Technol. 2015, 49, 8515-8522. [CrossRef] [PubMed]

23. Hanim, S.; Malek, N.; Ibrahim, Z. Analyses of surface area, porosity, silver release and antibacterial activity of amine-functionalized, silver-exchanged zeolite NaY. Vacuum 2017, 143, 344-347. [CrossRef]

24. González, D.M.; Santana, C.J.M.; González, A.G.; Pérez, N.; Millero, F.J. Oxidation of copper(I) in seawater at nanomolar levels. Mar. Chem. 2009, 115, 118-124. [CrossRef]

25. Arjmand, F.; Adriaens, A. Influence of $\mathrm{pH}$ and Chloride Concentration on the Corrosion Behavior of Unalloyed Copper in $\mathrm{NaCl}$ Solution: A Comparative Study between the Micro and Macro Scales. Materials 2012, 5, 2439-2464. [CrossRef]

26. El Warraky, A.; El Shayeb, H.; Sherif, E. Pitting corrosion of copper in chloride solutions. Anti Corros. Methods Mater. 2004, 51, 52-61. [CrossRef]

27. World Health Organization. Pocket Book of Hospital Care for Children: Guidelines for the Management of Common Illness with Limited Resources; World Health Organization: Geneva, Switzerland, 2005. Available online: http://www.who.int/childadolescent_health/documents_9241546700/en/index.html (accessed on 26 March 2020).

28. Sobsey, M.D.; Stauber, C.E.; Casanova, L.M.; Brown, J.M.; Elliott, M.A. Point of use household drinking water filtration: A practical effective solution for providing sustained access to safe drinking water in the developing world. Environ. Sci. Technol. 2008, 42, 4261-4267. [CrossRef]

29. Li, Q.; Mahendra, S.; Lyon, D.Y.; Brunet, L.; Lisa, M.V.; Li, D.; Alvarez, P.J.J. Antimicrobial nanomaterial for water disinfection and microbial control: Potential applications and implications. Water Res. 2008, 42, 4591-4602. [CrossRef]

30. Silbergeld, E.K.; Graham, J.; Price, L.B. Industrial Food Animal Production, Antimicrobial Resistance, and Human Health. Ann. Rev. Public Health 2008, 29, 151-169. [CrossRef]

31. Randall, C.P.; Gupta, A.; Jackson, N.; Busse, D.; O’Neill, A.J. Silver resistance in Gram-negative bacteria: A dissection of endogenous and exogenous mechanisms. J. Antimicrob. Chemother. 2015, 70, 1037-1046. [CrossRef]

32. Erickson, R.J.; Brooke, L.T.; Kahl, M.D.; Venter, F.V.; Harting, S.L.; Markee, T.P.; Spehar, R.L. Effects of laboratory test conditions on the toxicity of silver to aquatic organisms. Environ. Toxicol. Chem. 1998, 17, 572-578. [CrossRef]

33. Fabrega, J.; Fawcett, S.R.C.; Renshaw, J.C.; Lead, J.R. Silver Nanoparticle Impact on Bacterial Growth: Effect of $\mathrm{pH}$, Concentration, and Organic Matter. Environ. Sci. Technol. 2009, 43, 7285-7290. [CrossRef] [PubMed]

(C) 2020 by the authors. Licensee MDPI, Basel, Switzerland. This article is an open access article distributed under the terms and conditions of the Creative Commons Attribution (CC BY) license (http://creativecommons.org/licenses/by/4.0/). 